\title{
On the genus Rhodella, the emended orders Dixoniellales and Rhodellales with a new order Glaucosphaerales (Rhodellophyceae, Rhodophyta)
}

\author{
Joe Scott ${ }^{1}$, Eun Chan Yang ${ }^{2}$, John A. West ${ }^{3, *}$, Akiko Yokoyama ${ }^{4}$, Hee Jeong Kim ${ }^{2}$, Susan \\ Loiseaux de Goër ${ }^{5}$, Charles J. O'Kelly ${ }^{6}$, Evguenia Orlova', Su Yeon Kim ${ }^{7}$, Jeong Kwang \\ Park $^{7}$ and Hwan Su Yoon ${ }^{2,8, *}$ \\ ${ }^{1}$ Department of Biology, College of William \& Mary, Williamsburg, VA 23187, USA \\ ${ }^{2}$ Bigelow Laboratory for Ocean Sciences, 180 McKown Point Road, West Boothbay Harbor, ME 04575, USA \\ ${ }^{3}$ School of Botany, University of Melbourne, Parkville, Victoria 3010, Australia \\ ${ }^{4}$ Structural Biosciences, Graduate School of Life and Environmental Sciences, University of Tsukuba, 1-1-1 Tennodai, \\ Tsukuba, Ibaraki Pref. 305-8572, Japan \\ ${ }^{5} 11$ Rue des Moguerou, 29680 Roscoff, France \\ ${ }^{6}$ Friday Harbor Laboratories, University of Washington, 620 University Road, Friday Harbor, WA 98250, USA \\ ${ }^{7}$ Department of Biology, Chungnam National University, Daejeon 305-764, Korea \\ ${ }^{8}$ Department of Biological Sciences, Sungkyunkwan University, Suwon 440-746, Korea
}

The marine unicellular red algal genus Rhodella was established in 1970 by L. V. Evans with a single species R. maculata based on nuclear projections into the pyrenoid. Porphyridium violaceum was described by P. Kornmann in 1965 and transferred to Rhodella by W. Wehrmeyer in 1971 based on plastid features and the non-parietal position of the nucleus. Molecular and fine structural evidences have now revealed that Rhodella maculata and R. violacea are one species, so R. violacea has nomenclatural priority and the correct name is Rhodella violacea (Kornmann) Wehrmeyer. The status of families within Rhodellophyceae was examined. The order Dixoniellales and family Dixoniellaceae are emended to include only Dixoniella and Neorhodella. The order Rhodellales and family Rhodellaceae are emended to include Rhodella and Corynoplastis. Glaucosphaera vacuolata Korshikov and the Glaucosphaeraceae Skuja (1954) with an emended description are transferred to the Glaucosphaerales ord. nov.

Key Words: Dixoniellales; Glaucosphaerales ord. nov.; molecular phylogeny; Rhodellales; Rhodella violacea; ultrastructure; unicellular red algae

\section{INTRODUCTION}

The genus Rhodella was established by Evans (1970) to distinguish a unicellular red alga that possessed conspicuous ultrastructural features different from the other genera examined by transmission electron microscopy
(TEM) at that time, Porphyridium (e.g., Gantt and Conti 1965, Gantt et al. 1968) and Rhodosorus (Giraud 1962). Rhodella maculata (Evans 1970) has highly dissected chloroplast lobes attached to multiple sites of a central (c) This is an Open Access article distributed under the terms of the Creative Commons Attribution Non-Commercial License (http://creativecommons.org/licenses/by-nc/3.0/) which permits unrestricted non-commercial use, distribution, and reproduction in any medium, provided the original work is properly cited.
Received September 30, 2011, Accepted November 19, 2011

*Corresponding Author

E-mail: hsyoon2011@skku.edu, jwest@unimelb.edu.au Tel: +82-31-290-5915, Fax: +82-31-290-7015 
to eccentric naked pyrenoid. Pyrenoids are designated as being naked if they are not embedded in the chloroplast and instead border the cytoplasm, often partially surrounded by starch grains. The pyrenoid of Rhodella is unusual among red algal unicells in that the matrix does not contain thylakoids and it is invaded by one or two protrusions from the nucleus (Evans 1970, Patrone et al. 1991, Waller and McFadden 1995, Yokoyama et al. 2004). No other formally identified unicellular red algal genus has both of these subcellular features (Scott et al. 2008, Yang et al. 2010). In Wehrmeyer (1971) used TEM to characterize cells previously established as Porphyridium violaceum (Kornmann 1965) and determined that the cells bore a greater resemblance to R. maculata than to Porphyridium. Wehrmeyer transferred $P$. violacea to the genus Rhodella as R. violacea (Kornmann) Wehrmeyer. The two Rhodella species differed slightly from each other. The nuclear protrusions into the pyrenoid of $R$. violacea were not detected by Wehrmeyer (1971) but Patrone et al. (1991) noted their presence. In addition to having unique pyrenoids, both species lack a peripheral thylakoid in the chloroplast and Golgi bodies are associated only with endoplasmic reticulum (ER) and never with the nucleus or mitochondria (Scott et al. 2008, Yang et al. 2010, 2011).

In the 1980s, two more unicellular red algae were isolated, characterized by TEM and assigned to the genus Rhodella, $R$. reticulata (Deason et al. 1983) and R. cyanea (Billard and Fresnel 1986). The establishment of these two new algae as presumed species of Rhodella was again based on their ultrastructural dissimilarities to Porphyridium. But what was unexpected and left unexplained was the fact that these algae also did not bear any resemblance to either R. maculata or R. violacea. Furthermore, $R$. reticulata and R. cyanea clearly bore little resemblance to each other. Subsequent ultrastructural investigations resulted in transferring $R$. reticulata $(=R$. grisea, Fresnel et al. 1989) to a new genus Dixoniella as D. grisea (Scott et al. 1992) and $R$. cyanea was transferred to a new genus Neorhodella as N. cyanea (Scott et al. 2008). Recent molecular studies have confirmed the morphological work (Yokoyama et al. 2009) and R. maculata and R. violacea are currently assigned to the class Rhodellophyceae, Order Rhodellales, whereas D. grisea and N. cyanea are in the class Rhodellophyceae, Order Dixoniellales.

Yoon et al. (2006) established six classes of red algae in subphylum Rhodophytina, three of which include unicellular forms, the Porphyridiophyceae (Erythrolobus, Flintiella, Porphyridium, and Timspurckia), Stylonematophyceae (Rhodosorus and Rhodospora), and Rhodellophyceae (Corynoplastis, Dixoniella, Glaucosphaera,
Neorhodella, and Rhodella). For details of the unicellular red algae systematics of utilizing microscopic, molecular, and biochemical methods see Yoon et al. (2006), Scott et al. (2008), Yokoyama et al. (2009), and Yang et al. (2010, 2011).

This current work presents molecular, confocal microscopy, and electron microscopy details on culture strains of a unicellular red alga identified as Rhodella sp. isolated from Bodega Bay, CA and Friday Harbor WA, USA. For the comparison, we added information on the type species, R. maculata CCMP 736. We have emended the previously established orders Dixoniellales and Rhodellales to correct the placement of the genera Corynoplastis, Dixoniella, Neorhodella, and Rhodella and established the new order Glaucosphaerales to accommodate a single genus, Glaucosphaera.

\section{MATERIALS AND METHODS}

\section{Culture methods}

Procedures for isolation and culture were as described in West (2005). Isolate JAW 2347 (CCMP 3129) was obtained from a mud sample in a Salicornia salt marsh at Bodega Bay, CA, USA on April 15, 1980. O'Kelly's isolates RV-FHLa \& b (CCMP 3133, 3135) were obtained as epiphytes on the green alga Capsosiphon sp. on a seawall at Friday Harbor, WA, USA in March 2010. These three isolates are available from Bigelow Laboratory for Ocean Sciences, P. O. Box 475, 180 McKown Point Road, West Boothbay Harbor, ME 04575, USA.

\section{Confocal and Nomarski microscopy}

Fixation, staining, and observation methods were partially described in Yang et al. (2011). Cultured cells were transferred to $1.5 \mathrm{~mL}$ microtubes with $0.5 \mathrm{~mL}$ of culture medium, fixed with an equal volume of $3 \%$ paraformaldehyde in PHEM buffer [60 mM PIPES, 25 mM HEPES, $10 \mathrm{mM}$ EGTA, $2 \mathrm{mM} \mathrm{MgCl}\left(6 \mathrm{H}_{2} \mathrm{O}\right)$, $\mathrm{pH} 7.4$ ] for $15 \mathrm{~min}$. Ten $\mu \mathrm{L}$ of fixed cells were placed on a glass slide coated with $0.1 \mathrm{w} / \mathrm{v} \%$ poly-L-lysine and incubated for $10 \mathrm{~min}$ at room temperature. Then equal volumes of SlowFade Antifade (Invitrogen, Carlsbad, CA, USA) and 1,000× diluted SYBR Green I (Invitrogen) were added and incubated for $15 \mathrm{~min}$. Confocal images were taken with an inverted microscope Axiovert 100M with LSM 510 laser scanning equipment (Carl Zeiss AG, Jena, Germany) at the University of Tsukuba, and an Axio Observer LSM 700 instrument at Bigelow 
Laboratory for Ocean Sciences. Plastid autofluorescence and SYBR Green I fluorescence were detected with a 585 $\mathrm{nm}$ long pass filter and a 505 to $530 \mathrm{~nm}$ band pass filter, respectively, in the excitation line of a $488 \mathrm{~nm}$ argon laser and $543 \mathrm{~nm} \mathrm{He} / \mathrm{Ne}$ laser using a single-track mode. Living cells were observed with a Nikon microscope (Eclipse E600) equipped with Nomarski interference optics (Nikon Co. Ltd., Tokyo, Japan).

\section{Transmission electron microscopy}

Cells from cultures (grown in window light in 15 psu von Stosch enriched seawater) were filtered onto polyL-lysine coated $0.45 \mu \mathrm{m}$ Millipore filters (Bedford, MA, USA) and fixed for $2 \mathrm{~h}$ at ambient temperature in $2 \%$ glutaraldehyde in a $0.1 \mathrm{M}$ phosphate buffer solution $(\mathrm{pH}$ 6.8) with $0.15 \mathrm{M}$ sucrose. Following buffer rinses samples were post-fixed $2 \mathrm{~h}$ in the same buffer in $1 \% \mathrm{OsO}_{4}$ at $4^{\circ} \mathrm{C}$, rinsed thoroughly in $\mathrm{H}_{2} \mathrm{O}$, left in $50 \%$ acetone for $30 \mathrm{~min}$, and stored in a $70 \%$ acetone- $2 \%$ uranyl acetate solution at ambient temperature for $22 \mathrm{~h}$. Samples were then further dehydrated in a graded acetone series, infiltrated gradually, embedded in Embed 812 resin (Electron Microscopy Sciences, Hatfield, PA, USA), and polymerized at $70^{\circ} \mathrm{C}$ for 2-3 days. Thin sections were cut with an RMC MT6000XL ultramicrotome (RMC Inc., Tucson, AZ, USA). Sections were stained for 1 min with lead acetate. A Zeiss EM 109 electron microscope was used for observation and photography.

\section{DNA extraction, amplification and sequencing}

Genomic DNA was extracted from each culture strain using a DNeasy Plant Mini Kit (Qiagen, Hilden, Germany) according to the manufacturers' instructions. Polymerase chain reaction (PCR) and sequencing were performed with published and newly designed specific primer sets for each gene; psaAl30F-psaAl110R, psaA870F-psaA1600R and psaA971F-psaA1760R for $p s a \mathrm{~A}$ (Yoon et al. 2002, Yang and Boo 2004), rbcL43F (5'-CGTTAYGAATCTGGTGTAATYCC-3')-rbcL1414R (5'-TCAGCTGTATCTGTAGAAGTATA-3') for $r b c$ L. PCR amplification was performed in a total volume of $25 \mu \mathrm{L}$, containing 0.02 unit of Phusion High-Fidelity DNA polymerase (Finnzymes OY, Espoo, Finland), $5 \mu \mathrm{L}$ of the $5 \times$ Phusion HF Buffer (contain $1.5 \mathrm{mM} \mathrm{MgCl}_{2}$ ), $200 \mu \mathrm{M}$ of each dNTPs, $10 \mu \mathrm{M}$ of each primer and 1-20 ng of template DNA. PCR was carried out with an initial denaturation at $98^{\circ} \mathrm{C}$ for $30 \mathrm{~s}$, followed by 30 main amplification cycles of denaturation at $94^{\circ} \mathrm{C}$ for $10 \mathrm{~s}$, annealing at $50-55^{\circ} \mathrm{C}$ for $30 \mathrm{~s}$, extension at $72^{\circ} \mathrm{C}$ for $1 \mathrm{~min}$, and a final extension at $72^{\circ} \mathrm{C}$ for $7 \mathrm{~min}$. Amplified DNA was purified with the QIAquick PCR Purification kit (Qiagen) and sent to a commercial sequencing company. Electropherogram outputs for each specimen were edited using the program Chromas v.1.45 (http:// www.technelysium.com.au/chromas.html). Newly determined sequences were deposited in the GenBank databases (http://www.ncbi.nlm.nih.gov) under the accession numbers JN934872-JN934889 (see detail in Table 1).

\section{Phylogenetic analyses}

Published sequences were obtained from GenBank and aligned with newly determined sequences using ClustalW implemented SeaView version 4.2.5 (Gouy et al. 2010) and manually refined using Se-Al version 2.0a11 (http://tree.bio.ed.ac.uk/software/seal/). We excluded insertions of the nuclear small subunit rRNA (SSU rRNA) (Rhodella sp. MBIC10593, AB183619: \#538-1045; Thorea violacea SAG 51.94, AF342744: \#1356-1479) and introns of plastid psaA (Rhodella maculata CCMP 736, DQ308448: \#79-858; Rhosospora sordida UTEX 2621, DQ308453: \#226-723). There were no indel in $p s b \mathrm{~A}$ and $r b c \mathrm{~L}$. We used two data sets for tree search, (i) DNA and protein mixed data (total 3,070 characters; 1,881 base pairs of nuclear SSU rRNA + 1,189 amino acid sequences from plastid $p s a \mathrm{~A}, p s b \mathrm{~A}$, and $r b c \mathrm{~L}$ ) and (ii) DNA data (total 5,448 bp; 1,881 bp SSU rRNA + 3,567 bp plastid genes).

The evolutionary model for individual genes was chosen using the weighted Akaike information criterion (AIC) implemented in ModelGenerator version 0.85 (Keane et al. 2006). The selected best fitting models were the general time reversible (GTR) substitution with the gamma distributed rate heterogeneity $(\mathrm{G})$ for DNA data; the LG substitution (Le and Gascuel 2008) with empirical amino acid frequencies (F) and $\mathrm{G}(\mathrm{LG}+\mathrm{F}+\mathrm{G}$ model) for protein data. We used an independent model for each partition of the concatenated data. For example, it was used GTR + G model for SSU part and separate LG + F + G for $p s a \mathrm{~A}$, $p s b \mathrm{~A}$ and $r b c \mathrm{~L}$ parts of mixed data; separate GTR $+\mathrm{G}$ for individual gene of DNA data.

Maximum likelihood (ML) analyses were performed using RAxML version 7.2.8 (Stamatakis 2006). Tree likelihoods were estimated using 200 independent replications, each with a random starting point. The separate site-specific model was used for partitioned data and the automatically optimized SPR branch rearrangements were used during the rapid hill climbing tree search for each replication. Bootstrap analyses (MLB) were conducted using 1,000 replications with the same evolu- 
Table 1. Taxa list used in present study

\begin{tabular}{|c|c|c|c|c|c|}
\hline \multirow{2}{*}{ Taxa } & \multirow{2}{*}{ Strain or locality } & \multirow{2}{*}{$\frac{\text { Nuclear }}{\text { SSU }}$} & \multicolumn{3}{|c|}{ Plastid } \\
\hline & & & psaA & $p s b \mathrm{~A}$ & $r b c \mathrm{~L}$ \\
\hline \multicolumn{6}{|l|}{ Bangiophyceae } \\
\hline Bangia fuscopurpurea & SAG 59.81 & AF342745 & AY119699 & AY119735 & AY119771 \\
\hline Porphyra leucosticta & SAG 55.88 & AF342746 & DQ308442 & - & DQ308424 \\
\hline \multirow[t]{2}{*}{ Porphyra purpurea } & NHA 61946 & AF362363 & - & - & - \\
\hline & Avonport & - & U38804 & U38804 & U38804 \\
\hline \multicolumn{6}{|l|}{ Compsopogonophyceae } \\
\hline \multirow[t]{2}{*}{ Compsopogon caeruleus } & USA, Louisiana, Whiskey Chitto & AF087128 & - & - & AF087116 \\
\hline & USA, Alabama & - & DQ308445 & - & - \\
\hline Compsopogon caeruleus & SAG B 36.94 & AF342748 & AY119701 & AY119737 & - \\
\hline Rhodochaete parvula & UTEX 2715 & AJ880420 & AY119707 & AY119743 & AY119777 \\
\hline \multicolumn{6}{|l|}{ Cyanidiophyceae } \\
\hline Cyanidium caldarium & DBV 182 JAVA & - & AY541282 & AY541290 & AY541298 \\
\hline Galdieria daedala & IPPAS P508; Russia, Kunashira Island & AF441362 & AY541283 & AY541291 & AY541302 \\
\hline Galdieria maxima & IPPAS P507; Russia, Kunashira Island & AF441367 & AY391364 & AY391367 & AY391370 \\
\hline \multicolumn{6}{|l|}{ Florideophyceae } \\
\hline \multirow[t]{3}{*}{ Chondrus crispus } & EMBLCH307012 & DQ316999 & - & - & - \\
\hline & Canada, Nova Scotia & - & AY119710 & AY119746 & - \\
\hline & Northern Ireland, Co. Antrim, Bally Castle & - & - & - & U02984 \\
\hline \multirow[t]{2}{*}{ Palmaria palmata } & $\mathrm{n} / \mathrm{a}$ & Z14142 & - & - & U28421 \\
\hline & P244 & - & DQ787599 & DQ787639 & - \\
\hline Thorea violacea & SAG 51.94 & AF342744 & AY119712 & AY119747 & AF506271 \\
\hline \multicolumn{6}{|l|}{ Prophyridiophyceae } \\
\hline Flintiella sanguinaria & SAG 40.94 & AF342749 & AY119704 & AY119740 & AY119774 \\
\hline Porphyridium aerugineum & SAG 1380-2 & - & AY119705 & AY119741 & AY119775 \\
\hline \multicolumn{6}{|l|}{ Rhodellophyceae } \\
\hline Corynoplastis japonica & ССМР 3089 & JN934872 & JN934874 & JN934879 & JN934884 \\
\hline Corynoplastis japonica & TB4-T2 & AB045605 & - & - & - \\
\hline Dixoniella grisea & SAG 39.94 & AB045581 & AY119702 & AY119738 & AY119773 \\
\hline Dixoniella grisea & MF-G2 & AB045596 & - & - & - \\
\hline Glaucosphaera vacuolata & UTEX 1662 & AB045583 & DQ308447 & - & DQ308427 \\
\hline Neorhodella cyanea & RHO4 & FJ595494 & - & - & - \\
\hline Neorhodella cyanea & ССMP 3235 (= CCAP 1346/1, CCMP 3083, JAW 4072) & JN934873 & JN934875 & - & JN934885 \\
\hline Rhodella maculata & CCAP 1388/6; Sweden, Öland Island (Baltic Sea) & GU191839 & - & - & - \\
\hline Rhodella maculata & $\begin{array}{l}\text { CCMP 736; UK, England, Essex, Southend-on-Sea } \\
\text { (North Atlantic) }\end{array}$ & AJ880419 & DQ308448 & - & DQ308428 \\
\hline Rhodella maculata & Japan, Kagoshima, Amami Island (North Pacific) & АВ045608 & - & - & - \\
\hline Rhodella sp. & BC73C & AB045594 & - & - & - \\
\hline Rhodella sp. & GA6-T4 (North Pacific) & AB045591 & - & - & - \\
\hline Rhodella sp. & MBIC10593 & AB183619 & - & - & - \\
\hline Rhodella sp. & MBIC10825 & AB183648 & - & - & - \\
\hline Rhodella sp. & MBIC11021 & AB183652 & - & - & - \\
\hline Rhodella sp. & $\begin{array}{l}\text { Nagural; Japan, Okinawa, Ishigaki Island, Nagura } \\
\text { River (North Pacific) }\end{array}$ & AB045598 & - & - & - \\
\hline Rhodella sp. & $\begin{array}{l}\text { CCMP } 3129 \text { (= JAW 2347); USA, CA, } \\
\text { Bodega Marine Lab (North Pacific) }\end{array}$ & - & JN934876 & JN934880 & JN934886 \\
\hline Rhodella sp. & CCMP 3133 (= RV-FHLa, Friday Harbor Lab strain A) & - & JN934877 & JN934881 & JN934887 \\
\hline Rhodella sp. & CCMP 3135 (= RV-FHLb, Friday harbor Lab strain B) & - & JN934878 & JN934882 & JN934888 \\
\hline Rhodella violacea & BRW; USA, Alaska, BRW Elson Lag (North Pacific) & AB045604 & - & - & - \\
\hline Rhodella violacea & SAG 115.79; Germany & EU861395 & AY119706 & AY119742 & AY119776 \\
\hline Rhodella violacea & SAG B 115.79 & AB045580 & - & - & - \\
\hline Rhodella violacea & $\begin{array}{l}\text { UTEX } 2427 \text { (= CCMP 3229, JAW 3621, NEPCC-14, } \\
\text { NIBB-2010; North Sea) }\end{array}$ & AF168624 & - & JN934883 & JN934889 \\
\hline
\end{tabular}


Table 1. Continued

\begin{tabular}{|c|c|c|c|c|c|}
\hline \multirow{2}{*}{ Taxa } & \multirow{2}{*}{ Strain or locality } & \multirow{2}{*}{$\frac{\text { Nuclear }}{\text { SSU }}$} & \multicolumn{3}{|c|}{ Plastid } \\
\hline & & & psaA & $p s b \mathrm{~A}$ & $r b c \mathrm{~L}$ \\
\hline \multicolumn{6}{|l|}{ Stylonematophyceae } \\
\hline Bangiopsis subsimplex & PR21 & AF168627 & AY119700 & AY119736 & AY119772 \\
\hline Chroodactylon ornatum & SAG 103.79 & AF342751 & DQ308449 & - & DQ308429 \\
\hline Chroothece mobilis & FD Ott 01363 & - & DQ308450 & - & DQ308430 \\
\hline Rhodosorus marinus & SAG 116.79 & AF342750 & AY119708 & AY119744 & AY119778 \\
\hline Rhodosorus sp. & CCMP 1530 & AF168626 & DQ308454 & - & DQ308434 \\
\hline Rhodospora sordida & UTEX 2616 & FJ595495 & DQ308453 & - & DQ308433 \\
\hline \multirow[t]{2}{*}{ Stylonema alsidii } & UTEX 1424 & AF168633 & - & - & - \\
\hline & SAG 2.94 & - & AY119709 & AY119745 & AY119779 \\
\hline
\end{tabular}

GenBank accessions for new sequences are in bold.

tionary model setting as that used for the best topology search.

\section{RESULTS}

\section{Confocal observations}

The following observations were made with the culture isolate JAW 2347 (CCMP 3129). SYBR Green stain gave a green fluorescence to nuclear DNA as well as chloroplast and mitochondria genophores, whereas the whole chloroplast showed a red autofluorescence (Fig. 1). The nucleus of the interphase stage was always eccentric and associated with a pyrenoid (Fig. 1A-C). The single chloroplast had its pyrenoid centrally located and had many lobes positioned at the cell periphery. Plastid genophores were spherical to subspherical (about $0.25 \mu \mathrm{m}$ diameter) and present in the peripheral lobes. Two nuclei were found in some dividing cells (Fig. 1D). All observed characters were also found in R. maculata CCMP 736 (Fig. 1E $\&$ F), without any features distinguishing it from JAW 2347 (CCMP 3129).

\section{Transmission electron microscopy}

The cells were 8-12 $\mu \mathrm{m}$ in diameter and were coated by thin fibrillar material (Fig. 2). A discontinuous layer of ER was present beneath the cell membrane and appeared interconnected with the cell membrane by short tubules (Figs 2 \& 3D), as seen by Patrone et al. (1991) in Rhodella violacea, R. maculata and many other unicellular red algae. The spherical nucleus was approximately $3 \mu \mathrm{m}$ in diameter, occupying a peripheral location and was always closely associated with the more central pyrenoid (Fig. 2).
The nucleus contained one mostly central nucleolus (Fig. 2). In favorable sections usually one but occasionally two nuclear protrusions could be seen penetrating the pyrenoid as deep as $0.5-1 \mu \mathrm{m}$ (Figs $2 \& 3 \mathrm{~A}$ ). The protrusions always contained an electron dense, fibrillar material, not well seen in Figs 2 \& 3A. In the examination of several hundred cells, nuclear protrusions were detected in over 20.

Usually one pyrenoid was found in each cell but a few cells contained two pyrenoids. The pyrenoids were commonly larger than nuclei and were often bordered by starch that was also seen elsewhere in the cell, frequently near nuclei (Fig. 2). The moderately electron dense pyrenoid matrix was devoid of thylakoids (Figs 2 \& 3A). As observed in two-dimensional sections, 1-4 chloroplast lobes extended from the pyrenoid throughout the cytoplasm. Thylakoids were abundant and maintained consistent spacing from each other (Figs 2, 3B \& C), but phycobilisomes were not usually clearly seen. Peripheral thylakoids were absent (Figs 2 \& 3C). Electron dense clusters of spherical globules (plastoglobuli) were commonly seen at the outermost periphery of chloroplast lobes (Fig. 3C). Profiles of mitochondria were found throughout the cell (Figs 2, 3B \& C) as well as small electron transparent vacuoles (Figs $2 \& 3 \mathrm{~B}$ ). Golgi bodies were somewhat sparse and usually located at peripheral cell regions. All observed Golgi bodies had fused or closely appressed cisternae (Fig. 3B).

\section{Four-gene phylogeny}

Newly determined rhodellophycean nuclear SSU rRNA and three plastid protein-coding $p s a \mathrm{~A}, p s b \mathrm{~A}$, and $r b c \mathrm{~L}$ genes were aligned and used for the phylogenetic analysis. ML trees based on DNA + protein mixed data and 


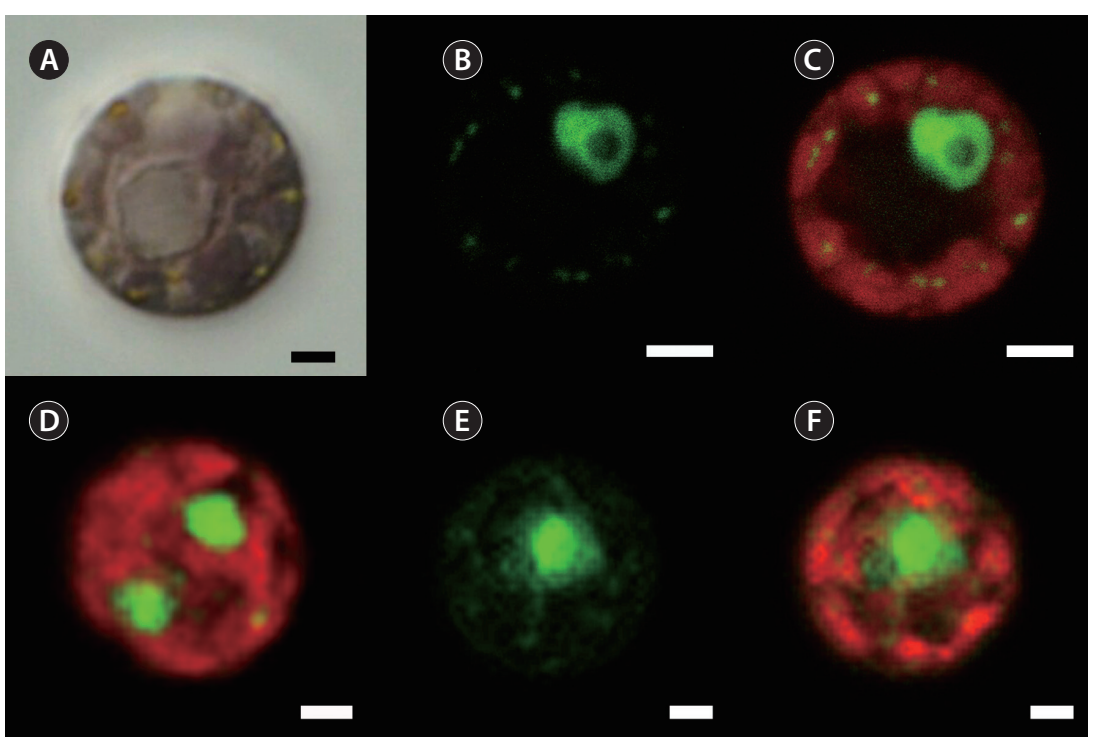

Fig. 1. Morphological characters from Rhodella violacea (JAW 2347 / CCMP 3129, A-D) and R. maculata (CCMP 736, E-F). (A) Nomarski differential interference microscopic image shows a single pyrenoid filled with uniform material and surrounded by starch. Plastid globules (yellowish orange) are scattered at the cell surfaces. A single eccentric nucleus is situated beside the pyrenoid. (B) Confocal microscopic image from single focal level. Fluorescent SYBR Green staining show a single nucleus with single nucleolus and chloroplast genophores as small particles in the lobes at the cell perimeter. (C) Combined image of SYBR Green staining and plastid autofluorescence (red). A pyrenoid region is the central dark space. Plastid genophores (greenish-yellow) are located in the central areas of chloroplast lobes. (D) Dividing cell with two nuclei. (E) Confocal microscopy of CCMP 736 shows a single nucleus and chloroplast genophores similar to JAW 2347. (F) Combined images of SYBR Green staining and plastid autofluorescence from CCMP 736. Scale bars represent: A-F, $2.0 \mu \mathrm{m}$.

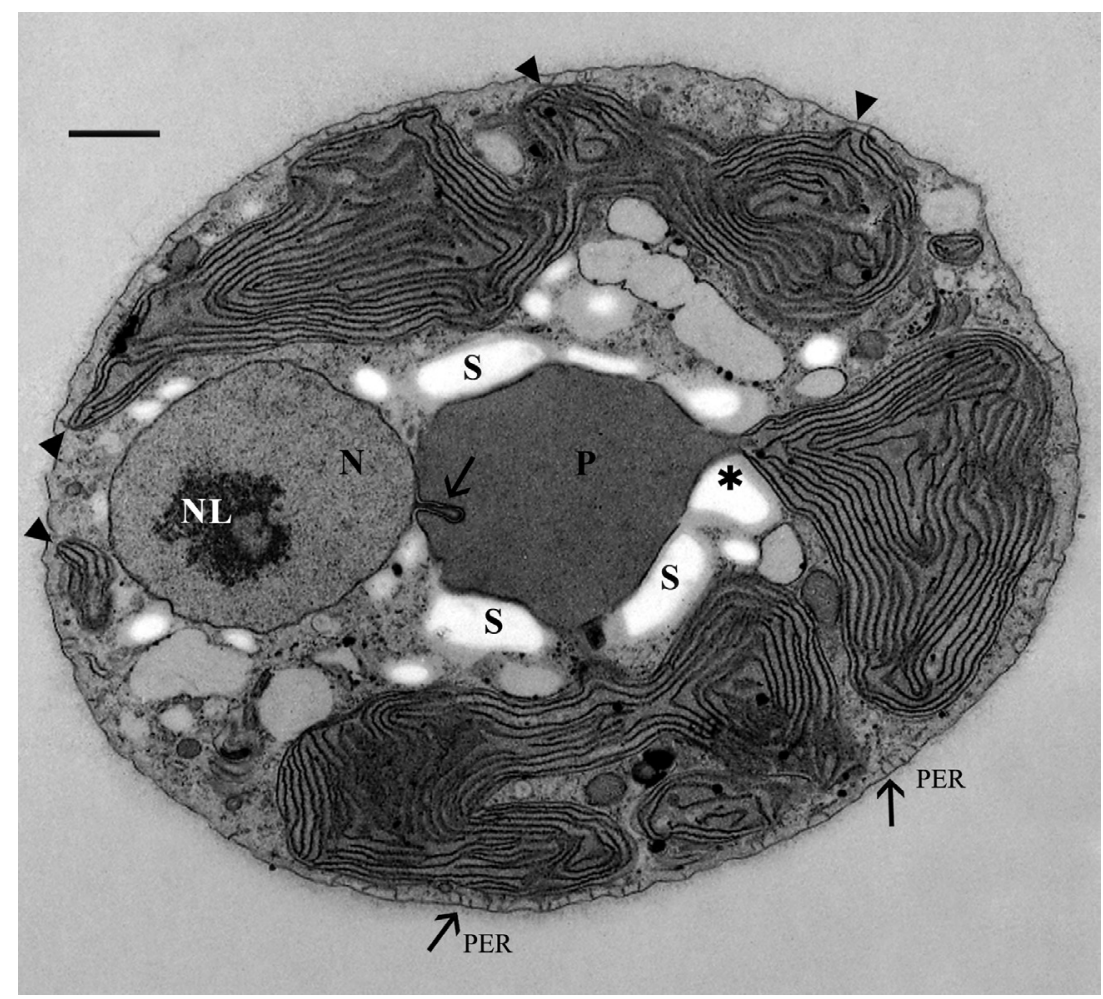

Fig. 2. Rhodella violacea (JAW 2347 / CCMP 3129) ultrastructure. Low magnification electron micrograph of a medially sectioned cell. The nucleus $(\mathrm{N})$ is peripheral with a centrally located nucleolus (NL). A nuclear extension (arrow) projects into the adjacent pyrenoid (P), which is surrounded by starch grains (S). The pyrenoid lacks thylakoids and is seen connected to one of the chloroplast lobes (asterisk). A peripheral thylakoid is absent, as detected in several regions of the chloroplast lobes (arrowheads). A peripheral endoplasmic reticulum (ER) system (PER) is visible in some areas just in side of the cell membrane. Scale bar represents: $1.0 \mu \mathrm{m}$. 

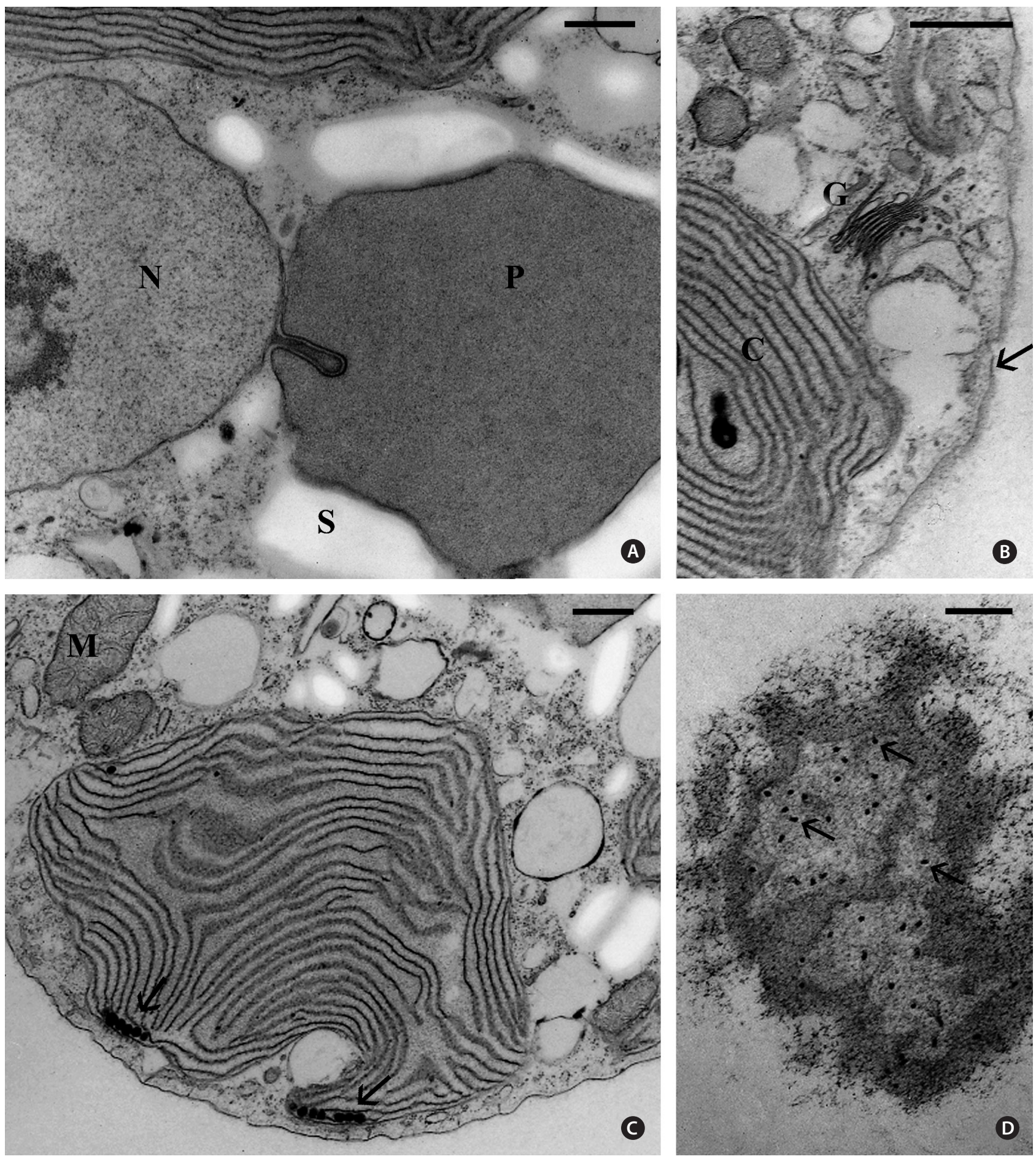

Fig. 3. Rhodella violacea (JAW 2347 / CCMP 3129) ultrastructure. (A) The nuclear protrusion contains electron dense material. N, nucleus; P, pyrenoid; S, starch. (B) A Golgi body (G) is near the cell membrane (arrow). An expanded portion of endoplasmic reticulum (ER) is seen between the cell membrane and the Golgi cis-region. Golgi cisternae are closely appressed in the mid-region. C, chloroplast lobe. (C) Electron dense globules (plastoglobuli, arrows) are consistently located at the periphery of chloroplast lobes. M, mitochondrion. (D) Tubules of the peripheral ER system (arrows) are seen in cross section. Scale bars represent: A-C, $0.5 \mu \mathrm{m} ; \mathrm{D}, 0.1 \mu \mathrm{m}$. 
DNA data were consistent with each other, except for the position of Porphyridiophyceae (Fig. 4). The Porphyridiophyceae grouped with a Bangiophyceae / Florideophyceae / Rhodellophyceae clade in the DNA + protein mixed data, whereas it grouped together with the Compsopogonophyceae / Stylonematophyceae clade in the DNA-only tree. However, this incongruence was not supported statistically (less than 50\% bootstrap value in each phylogeny).

Multigene trees supported the monophyly of Rhodellophyceae strongly (MLB and mixed and DNA 100\%). Within the rhodellophycean monophyly, two subclades were identified: i) the Rhodellales clade (MLB mixed and DNA 100\%) including Rhodella and Corynoplastis, ii) the Glaucosphaerales and Dixoniellales clade (MLB mixed 97\% and DNA 100\%), including Glaucosphaera, Dixoniella, and Neorhodella. Within Rhodellales, all 16 Rhodella isolates were strongly grouped together (MLB mixed and DNA $100 \%$ ). However, they did not make monophyletic groups for each species of $R$. violacea (BRW, UTEX 2427, SAG 115.79) and R. maculata (CCMP 736, CCAP 1388/6, Japan: Amami). Rhodella sp. BC73C was separated from the rest of the isolates (MLB mixed 91\% and DNA 94\%). Four isolates (MBIC11021, MBIC10825, MBIC10593 and Japan: Amani) were grouped together (MLB mixed 79\% and DNA 77\%).

Sequence divergences within Rhodella isolates ranged from 0 to $37 \mathrm{bp}$ (2\% p distance; between MBIC 10593 and GA6-T4) in SSU rRNA, up to 18 bp (1.5\%; between JAW 2347 and UTEX 2427) in $r b c \mathrm{~L}$, up to $6 \mathrm{bp}(0.7 \%$; between RV-FHLa and SAG 115.79) in $p s b A$, and up to 2 bp $(0.1 \%$; between CCMP 736 and SAG 115.79) in psaA. Sequence divergences between Rhodella sp. BC73C and the rest of the isolates were clearly higher, ranging from $68(3.6 \%$, with $R$. violacea UTEX 2427) to 78 bp (4.1\%, with R. maculata Japan: Amani isolate) in the SSU rRNA sequence.

\section{DISCUSSION}

Our ultrastructural examination of JAW 2347 revealed two cell characters found in no other unicellular red algae except R. maculata and R. violacea (Evans 1970, Wehrmeyer 1971, Patrone et al. 1991): the pyrenoid matrix lacked thylakoids and was penetrated by one or more protrusions from the closely associated nucleus. Also present in Rhodella were Golgi bodies associated only with ER, a chloroplast lacking a peripheral encircling thylakoid, and accumulations of electron dense globules (plastoglobuli) in the outer chloroplast lobes at the cell periphery.
The only other member of the Rhodellophyceae possessing Golgi bodies associated with ER is Corynoplastis. Golgi bodies in Dixoniella, Glaucosphaera, and Neorhodella are consistently situated near the outer membrane of the nuclear envelope. No other red alga has this peculiar Golgi association. However, the fact that the ER and the outer membrane of the nuclear envelope are both functional equivalents is what unifies Golgi differences in the Rhodellophyceae (see discussion in Scott et al. 2008). In contrast, Golgi bodies in all members of the Porphyridiophyceae, Bangiophyceae, and Florideophyceae are always closely associated with mitochondria. Only the relatively few genera in the Stylonematophyceae and Compsopogonophyceae have an ER-Golgi alignment as is routinely found in most other eukaryotes. An additional Golgi attribute found only in the other rhodellophycean unicells and sporangia of certain multicellular red algae (Scott et al. 2008) is fusion or apposition of Golgi cisternae. The significance of this unusual trait is unknown.

The presence or absence of a peripheral thylakoid is variable in the Rhodellophyceae. Dixoniella, Glaucosphaera, and Corynoplastis possess a peripheral thylakoid, whereas Rhodella and Neorhodella do not. The four genera of Porphyridiophyceae, Erythrolobus, Flintiella, Porphyridium, and Timspurckia all lack this feature. Within the Stylonematophyceae, Compsopogonophyceae, Bangiophyceae, and Florideophyceae only the sporophyte (conchocelis) stages of Bangia and Porphyra (Pueschel 1990) and vegetative cells of Rhodachlya (Rhodachlyaleales, Florideophyceae) (West et al. 2008) lack a peripheral thylakoid. The phylogenetic and functional significance of the presence or absence of this thylakoid is unknown. Electron dense globules or plastoglobuli are fairly commonly seen in red algal chloroplasts (Pueschel 1990). Plastoglobuli clusters located in the peripheral lobes of chloroplasts are present in all members of Rhodellophyceae but are absent in other unicellular red algae (Scott et al. 2008, Yokoyama et al. 2009). See Deason et al. (1983) for a detailed discussion of plastoglobuli (stigmata = eyespots) in chloroplasts of unicellular red algae.

It is obvious that the presence or absence of starch grains closely bordering the naked pyrenoids of Rhodella is a variable. Some cells of JAW 2347 isolate (CCMP 3129) had pyrenoids free of starch, whereas other cells showed a close association. Pyrenoids in R. violacea cells observed by Wehrmeyer (1971) were surrounded by starch, whereas cells of the same culture strain studied by Patrone et al. (1991) lacked starch in the region adjacent to the nucleus where the nuclear protrusions are located. However, as Wehrmeyer (1971) did not find any nuclear protrusions 


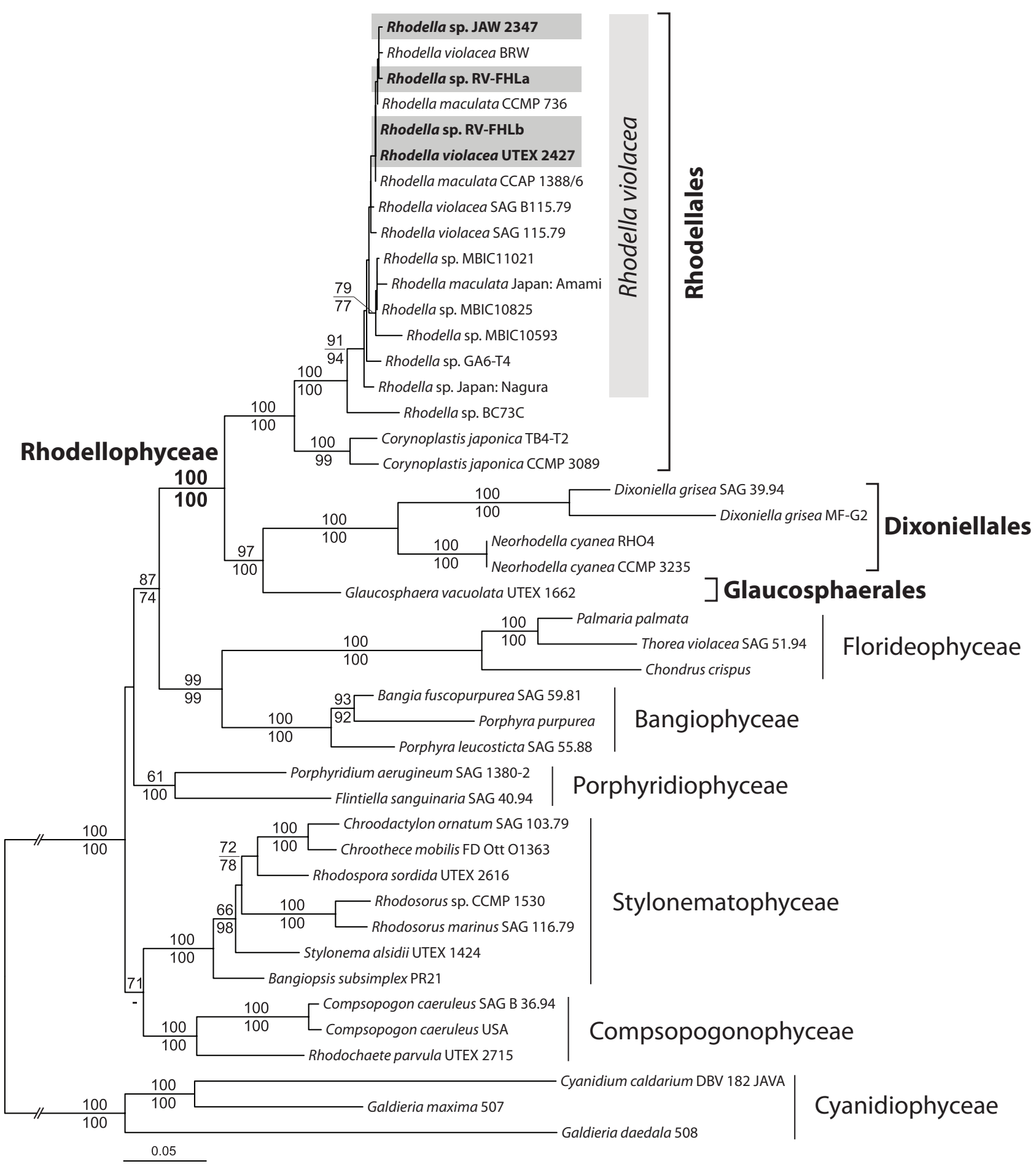

Fig. 4. The maximum likelihood phylogeny of Rhodella violacea is based on nuclear small subunit (SSU) rRNA + plastid protein $p s a A$, $p s b A$, and $r b c L(-\operatorname{lnL}=26232.95)$. Likelihood is estimated under the general time reversible $(G T R)+G$ model for the DNA part and separate LG + G + F model for the individual protein gene part. The maximum likelihood $(\mathrm{ML})$ bootstrap support values are shown on the branches (from DNA + protein mixed data) and under branch (from DNA data). 
in his study, it is possible that starch could likewise be absent in the protrusion zone of the isolate of $R$. violacea that he examined. All regions of pyrenoids in R. maculata are bordered by starch grains, even between the pyrenoids and nuclei in the protrusion zone (Evans 1970, Patrone et al. 1991). However, in R. maculata cells studied by Waller and McFadden (1995), several micrographs showed pyrenoids heavily bordered by starch, whereas one micrograph showed a starch-free pyrenoid. Most likely these observed variations in starch content and localization are more likely dependent upon differences in culture conditions used or cell cycle stage studied rather then reliable indicators to discriminate taxa.

The nuclear protrusions in strain JAW 2347 (CCMP 3129), R. violacea (Patrone et al. 1991), and those in $R$. maculata observed by Evans (1970), Patrone et al. (1991), and Waller and McFadden (1995) were variable length but all contained an electron dense material. Waller and McFadden (1995) determined that the material was nonribosomal RNA and could possibly serve a structural role. Two protrusions were occasionally seen in a single cell of R. violacea (Patrone et al. 1991) and, two protrusions were commonly found by Waller and McFadden (1995) in $R$. maculata cells by serial sectioning.

The low molecular weight carbohydrate (LMWC) mannitol is present in all Rhodellophycae including JAW 2347 (CCMP 3129) (Karsten et al. 1999, 2003, Scott et al. 2008, Nitschke et al. 2010).

JAW 2347 (CCMP 3129) is readily recognized as a species of Rhodella based on electron microscopic and molecular evidence. As seen in thin sections: (1) Golgi bodies were consistently associated with ER and no other organelles (e.g., mitochondria or the nucleus), (2) the chloroplast is highly dissected with thylakoid-filled lobes containing peripheral plastoglobuli and no peripheral thylakoid, (3) the matrix of the central to eccentric pyrenoid is devoid of thylakoids but penetrated by one or two unique digitate protrusions arising from the adjacent nucleus. No other unicellular red algal genus has this combination of ultrastructural characters (Scott et al. 2008).

The concatenated phylogeny (nuclear SSU rRNA + plastid $p s a \mathrm{~A}, p s b \mathrm{~A}$, and $r b c \mathrm{~L}$ ) is congruent with the seven-class system of Rhodophyta and the monophyly of Rhodellophyceae (Yoon et al. 2006, 2010). In the present study, as rhodellophycean ingroup taxa increased, there was greater ML bootstrap support for the sister relationship of Rhodellophyceae to the Bangio-Florideophyceae clade than that of previous studies, i.e., $>50 \%$ from SSU rRNA tree in Yokoyama et al. (2009); 53\% from a ninegene tree in Yoon et al. (2006); 58\% from a two-gene tree in Yang et al. (2010). These results support the idea that broad taxa sampling increased robustness of the tree (Rokas and Carroll 2005, Parfrey et al. 2010). Our phylogeny suggest that the Rhodellophyceae is the sister class of the Bangiophyceae-Florideophyceae clade. Within the Rhodellophyceae, the Glaucosphaerales and Dixoniellales are sister group taxa separated from the Rhodellales.

In the Rhodella phylogeny, all Rhodella isolates (except isolate BC73C) were grouped together, and neither $R$. violacea nor R. maculata were a monophyletic group in the genus. Most isolates were strongly grouped together in the tree. The results showed low sequence divergences in SSU rRNA $(2 \%)$ and three plastid genes $(<2 \%)$, which were significantly lower than those of other unicellular red algae (e.g., 11-15\% divergence in psaA of Erythrolobus spp.) (Yang et al. 2010). However, isolate BC73C is genetically distinct within Rhodella and may be a distinct species, but further investigation is required.

\section{Redefinition of the Rhodellophyceae orders and families}

Wynne and Schneider (2010) indicated that the family Dixoniellaceae established by Yokoyama et al. (2009) was invalid because the family Glaucosphaeraceae, which originally included only Glaucosphaera, was established by Skuja (1954) and had precedence. However, based on the structural characters, cell activity (i.e., continuous Golgi vesicle formation and extrusion), and molecular evidence, we have placed the genus Glaucosphaera in the separate new order Glaucosphaerales Yang, Scott, Yoon and West in which the family Glaucosphaeraceae Skuja is now placed. The Glaucosphaerales is phylogenetically closely related to the Dixoniellales.

Glaucosphaerales ord. nov., Yang, Scott, Yoon and West. The order, family and genus are defined as a unicellular freshwater red alga, containing a blue green chloroplast with a peripheral thylakoid, plastoglobuli clusters, no pyrenoid, active perinuclear Golgi bodies continuously producing and rapidly ejecting small vesicles from the cell, cells larger than most unicellular reds (to $25 \mu \mathrm{m}$ diameter) (Broadwater et al. 1995, Pickett-Heaps et al. 2001, Wilson et al. 2006), LMWCs unknown.

Glaucosphaeraceae Skuja (1954). Same characters as the order. The only taxon at present is Glaucosphaera vacuolata Korshikov (1930), known as the original type specimen from a large pond in a meadow at the outskirts of the city Charkova (Kharkov), Ukraine, in August 1929 and a single collection and culture obtained by Richard Starr in May 1968 in soil from a horse pond near Elletts- 
ville, IN, USA.

Dixoniellales and Dixoniellaceae Yokoyama et al. (2009). Emended ordinal and family description: single chloroplast with a single or multiple pyrenoids, plastoglobuli at chloroplast periphery, Golgi bodies perinuclear, mannitol as the only LMWC. Dixoniella and Neorhodella are now the only genera in this order and family.

Rhodellales Yoon et al. (2006). As originally defined by Yoon et al. (2006) this order includes Rhodella, Dixoniella and Glaucosphaera. Yokoyama et al. (2009) placed Dixoniella and Neorhodella in the Dixoniellales Yokoyama et al. (2009).

Emended ordinal description: unicellular red algae, a single highly lobed plastid with single or multiple pyrenoids, plastoglobuli at plastid periphery, scattered Golgi associated with ER, contain mannitol as a LMWC.

Rhodellaceae Yoon et al. (2006) now contains only two genera Rhodella and Corynoplastis (Yokoyama et al. 2009). The genus description of Rhodella is emended to specify that digitate nuclear intrusions occur in the pyrenoid and the pyrenoid matrix is devoid of thylakoids. The two currently recognized species [R. maculata Evans and $R$. violacea (Kornmann) Wehrmeyer] are merged as one, R. violaceum (Kornmann) Wehrmeyer. Rhodella violacea is used because it is the basionym Porphyridium violaceum Kornmann (1965), and the name with priority.

\section{ACKNOWLEDGEMENTS}

Laboratory culture investigations were partially supported by grants to JAW from the Australian Research Council, Australian Biological Resources Study and Hermon Slade Foundation. This project was also partially supported by the National Science Foundation (DEB0937975, 0934176), USA and the Marine Biotechnology Program funded by Ministry of Land, Transport, and Maritime Affairs, Korea to HSY, and by the Japan Society for the Promotion of Science (Grants-in-Aid for Scientific Research 20570081) to AY. We appreciate the valuable comments from the reviewer that improved the manuscript immensely.

\section{REFERENCES}

Billard, C. \& Fresnel, J. 1986. Rhodella cyanea nov. sp., une nouvelle Rhodophyceae unicellulaire. C. R. Acad. Sci. Serie IIII Sci. Vie 302:271-276.

Broadwater, S. T., Scott, J. L., Goss, S. P. A. \& Saunders, B. D.
1995. Ultrastructure of vegetative organization and cell division in Glaucosphaera vacuolata Korshikov (Porphyridiales, Rhodophyta). Phycologia 34:351-361.

Deason, T. R., Butler, G. L. \& Rhyne, C. 1983. Rhodella reticulata sp. nov., a new coccoid Rhodophytan alga (Porphyridiales). J. Phycol. 19:104-111.

Evans, L. V. 1970. Electron microscopical observations on a new red algal unicell, Rhodella maculata gen. nov., sp. nov. Br. Phycol. J. 5:1-13.

Fresnel, J., Billard, C., Hindák, F. \& Pekárková, B. 1989. New observations on Porphyridium griseum Geitler $=$ Rhodella grisea (Geitler) comb. nova (Porphyridiales, Rhodophyceae). Plant Syst. Evol. 164:253-262.

Gantt, E. \& Conti, S. F. 1965. The ultrastructure of Porphyridium cruentum. J. Cell Biol. 26:365-381.

Gantt, E., Edwards, M. R. \& Conti, S. F. 1968. Ultrastructure of Porphyridium aerugineum, a blue-green colored rhodophytan. J. Phycol. 4:65-71.

Giraud, G. 1962. Les infrastructures de quelques algues et leur physiologie. J. Microsc. 1:251-274.

Gouy, M., Guindon, S. \& Gascuel, O. 2010. SeaView version 4: a multiplatform graphical user interface for sequence alignment and phylogenetic tree building. Mol. Biol. Evol. 27:221-224.

Karsten, U., West, J. A., Zuccarello, G. C., Engbrodt, R., Yokoyama, A., Hara, Y. \& Brodie, J. 2003. Low molecular weight carbohydrates of the Bangiophycidae (Rhodophyta). J. Phycol. 39:584-589.

Karsten, U., West, J. A., Zuccarello, G. C., Nixdorf, O., Barrow, K. D. \& King, R. J. 1999. Low molecular weight carbohydrate patterns in the Bangiophyceae (Rhodophyta). J. Phycol. 35:967-976.

Keane, T. M., Creevey, C. J., Pentony, M. M., Naughton, T. J. \& McInerney, J. O. 2006. Assessment of methods for amino acid matrix selection and their use on empirical data shows that ad hoc assumptions for choice of matrix are not justified. BMC Evol. Biol. 6:29.

Kornmann, P. 1965. Porphyridium violaceum, eine marine neue Art. Helgol. Wiss. Meeresunters. 12:420-423.

Korshikov, A. A. 1930. Glaucosphaera vacuolata, a new member of the Glaucophyceae. Arch. Protistenkunde 70:217222.

Le, S. Q. \& Gascuel, O. 2008. An improved general amino acid replacement matrix. Mol. Biol. Evol. 25:1307-1320.

Nitschke, U., Boedeker, C., Karsten, U., Hepperle, D. \& Eggert, A. 2010. Does the lack of mannitol accumulation in an isolate of Rhodella maculata (Rhodellophyceae, Rhodophyta) from the brackish Baltic Sea indicate a stressed population at the distribution limit? Eur. J. Phycol. 45:436-449. 
Parfrey, L. W., Grant, J., Tekle, Y. I., Lasek-Nesselquist, E., Morrison, H. G., Sogin, M. L., Patterson, D. J. \& Katz, L. A. 2010. Broadly sampled multigene analyses yield a wellresolved eukaryotic tree of life. Syst. Biol. 59:518-533.

Patrone, L. M., Broadwater, S. T. \& Scott, J. L. 1991. Ultrastructure of vegetative and dividing cells of the unicellular red algae Rhodella violacea and Rhodella maculata. J. Phycol. 27:742-753.

Pickett-Heaps, J. D., West, J. A., Wilson, S. M. \& McBride, D. L. 2001. Time-lapse video microscopy of cell (spore) movement in red algae. Eur. J. Phycol. 36:9-22.

Pueschel, C. 1990. Cell structure. In Cole, K. M. \& Sheath, R. G. (Eds.) Biology of the Red Algae. Cambridge University Press, New York, pp. 7-41.

Rokas, A. \& Carroll, S. B. 2005. More genes or more taxa? The relative contribution of gene number and taxon number to phylogenetic accuracy. Mol. Biol. Evol. 22:1337-1344.

Scott, J., Yokoyama, A., Billard, C., Fresnel, J., Hara, Y., West, K. A. \& West, J. A. 2008. Neorhodella cyanea, a new genus in the Rhodellophyceae (Rhodophyta). Phycologia 47:560-572.

Scott, J. L., Broadwater, S. T., Saunders, B. D., Thomas, J. P. \& Gabrielson, P.W. 1992. Ultrastructure of vegetative organization and cell division in the unicellular red alga Dixoniella grisea gen. nov. (Rhodophyta) and a consideration of the genus Rhodella. J. Phycol. 28:649-660.

Skuja, H. 1954. Abteilung: Glaucophyta. In Melchior, H. \& Werdermann, E. (Eds.) A. Englers Syllabus der Pflanzenfamilien, 12. Aufl. 1. Band. Borntraeger, Berlin, pp. 56-57.

Stamatakis, A. 2006. RAxML-VI-HPC: maximum likelihoodbased phylogenetic analyses with thousands of taxa and mixed models. Bioinformatics 22:2688-2690.

Waller, R. F. \& McFadden, G. I. 1995. Morphological and cytochemical analysis of an unusual nucleus-pyrenoid association in a unicellular red alga. Protoplasma 186:131141.

Wehrmeyer, W. 1971. Elektronmikroskopische Untersuchung zur Feinstruktur von Porphyridium violaceum Kornmann mit Bemerkungen über seine taxonomische Stellung. Arch. Mikrobiol. 75:121-139.

West, J. A. 2005. Long term macroalgal culture maintenance. In Anderson, R. (Ed.) Algal Culturing Techniques. Academic Press, New York, pp. 157-163.

West, J. A., Scott, J. L., West, K. A., Karsten, U., Clayden, S. L. \& Saunders, G. W. 2008. Rhodachlya madagascarensis gen. et sp. nov.: a distinct acrochaetioid represents a new order and family (Rhodachlyales ord. nov., Rhodachlyaceae fam. nov.) of the Florideophyceae (Rhodophyta). Phycologia 47:203-212.

Wilson, S. M., Pickett-Heaps, J. D. \& West, J. A. 2006. Vesicle transport and the cytoskeleton in the unicellular red alga Glaucosphaera vacuolata. Phycol. Res. 54:15-20.

Wynne, M. J. \& Schneider, C. W. 2010. Addendum to the synoptic review of red algal genera. Bot. Mar. 53:291-299.

Yang, E. C. \& Boo, S. M. 2004. Evidence for two independent lineages of Griffithsia (Ceramiaceae, Rhodophyta) based on plastid protein-coding $p s a \mathrm{~A}, p s b \mathrm{~A}$, and $r b c \mathrm{~L}$ gene sequences. Mol. Phylogenet. Evol. 31:680-688.

Yang, E. C., Scott, J., West, J. A., Orlova, E., Gauthier, D., Küpper, F. C., Yoon, H. S. \& Karsten, U. 2010. New taxa of the Porphyridiophyceae (Rhodophyta): Timspurckia oligopyrenoides gen. et sp. nov. and Erythrolobus madagascarensis sp. nov. Phycologia 49:604-616.

Yang, E. C., Scott, J., West, J. A., Yoon, H. S., Yokoyama, A., Karsten, U., Loiseaux de Goër, S. \& Orlova, E. 2011. Erythrolobus australicus sp. nov. (Porphyridiophyceae, Rhodophyta): a description based on several approaches. Algae 26:167-180.

Yokoyama, A., Sato, K. \& Hara, Y. 2004. The generic delimitation of Rhodella (Porphyridiales, Rhodophyta) with emphasis on ultrastructure and molecular phylogeny. Hydrobiologia 512:177-183.

Yokoyama, A., Scott, J. L., Zuccarello, G. C., Kajikawa, M., Hara, Y. \& West, J. A. 2009. Corynoplastis japonica gen. et sp. nov. and Dixoniellales ord. nov. (Rhodellophyceae, Rhodophyta) based on morphological and molecular evidence. Phycol. Res. 57:278-289.

Yoon, H. S., Hackett, J. D. \& Bhattacharya, D. 2002. A single origin of the peridinin- and fucoxanthin-containing plastids in dinoflagellates through tertiary endosymbiosis. Proc. Natl. Acad. Sci. U. S. A. 99:11724-11729.

Yoon, H. S., Müller, K. M., Sheath, R. G., Ott, F. D. \& Bhattacharya, D. 2006. Defining the major lineages of red algae (Rhodophyta). J. Phycol. 42:482-492.

Yoon, H. S., Zuccarello, G. C. \& Bhattacharya, D. 2010. Evolutionary history and taxonomy of red algae. In Seckbach, J. \& Chapman, D. J. (Eds.) Red Algae in the Genomic Age: Cellular Origin, Life in Extreme Habitats and Astrobiology. Springer, Heidelberg, pp. 25-42. 